\title{
ANALYSIS OF FUNDAMENTAL FACTORS' EFFECT ON STOCK RETURN OF PROPERTY: A CASE STUDY OF PROPERTY, REAL ESTATE, AND BUILDING CONSTRUCTION SECTOR OF COMPANIES LISTED ON THE INDONESIA STOCK EXCHANGE IN 2012-2016
}

\author{
Fitri Piralanasih, Magister \\ Matrodji Mustafa, Lecturer \\ Mercu Buana University, Indonesia \\ ${ }^{*}$ E-mail: f.pirala@yahoo.com \\ ORCID: 0000-0002-8724-204X
}

\begin{abstract}
The purpose of this study is to analyse the impact of fundamental factors on stock return of property, real estate, and building construction companies listed on the Indonesia Stock Exchange for the period of 2012-2016. The samples of this study are 41 property, real estate and bulding construction companies listed in Indonesia Stock Exchange for the period of 2012-2016. The results showed that debt to equity ratio and price to book value partially have positive significant effect toward the stock return of property, real estate, and building construction companies listed on the Indonesia Stock Exchange.
\end{abstract}

\section{KEY WORDS}

Stock return, property, real estate, Indonesia, business.

The role of capital market in Indonesia economy has economic and financial function. Economically, capital market is one of a long-term fund flows systems, in which can be allocated by the government to the other sectors of investment in order to get return. Financially, capital market can be a media for an individual investor or a company to allocate their investement funds and get the particular return. The growing of capital market shows the trust of investors to invest in Indonesia. Making investment in the instrument of share has more risk than the other instrument of investation, such as obligation, and saving. Investors have to be able to predict the level of expected return and the possibility of balance outcome.

Each of investor in capital market has to get fundamental or technical information about the current investment instruments before investing their funds. Fundamental information is issued by issuer or the administrator of stock exchange. Fundamental analysis is started from the general flow of the company. Next, it will go to industrial sectors, and finally, it is evaluated to the issued stock price. However, technical analysis is based on the data (changing) of the stock price in the past as an attempt to predict the stock price in the future (Halim, 2005). Investors usually use fundamental information because it reflects the situation of a company based on issued financial report. Some financial ratios, cash flows, and the other measured performances will be connected to the stock return. Great result of fundamental indicators is expected to give great response to the market and increase the stock prince in capital market.

Several sectors that are traded in Indonesian Stock Exchange are property, real estate, building construction sector, which lately becomes famous because of oversupply in several types of property. According to the growth chart of Property Price Index in 2014 to 2016, there was a fluctuative price in the sector of property, especially in the lease of apartment and hotel. The decline of price was predictably caused by the growth of limitated demand compares to the rising of supply. Generally, the decline in 2014 was followed by rising of price in the second quarter in 2015 then it went down in 2016 (Figure 1).

Based on Residential Property Price Index, there was a slowly increase of residential property price. In 2013, there was a high rising of the price due to the increasing price of material building, wages work, and fuel. Nonetheles, in the end 2016, IHPR shows that there was a slow increase in residential property price (Figure 2). 


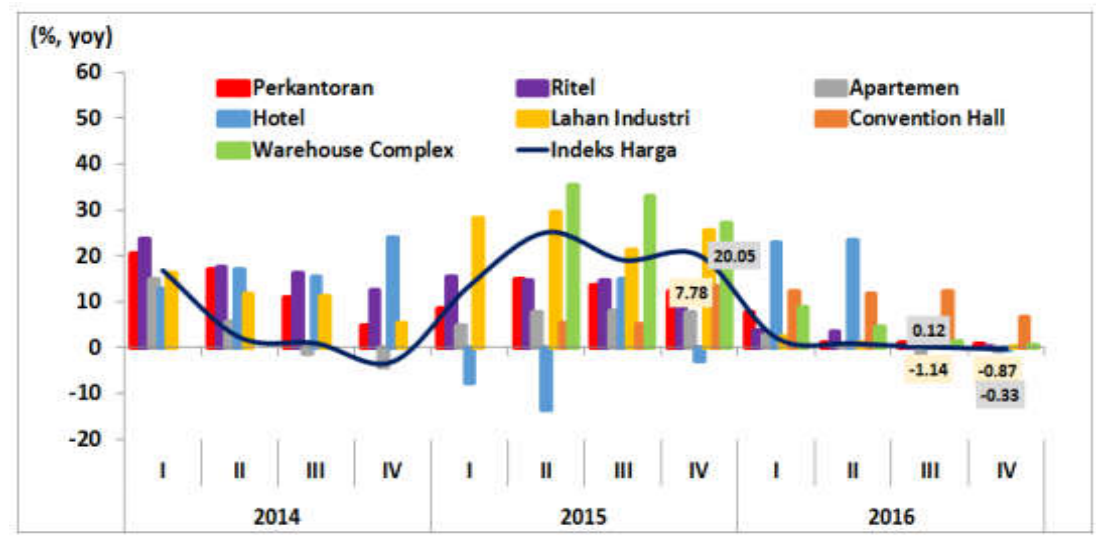

Figure 1 - Growth of Commercial Property Price Index

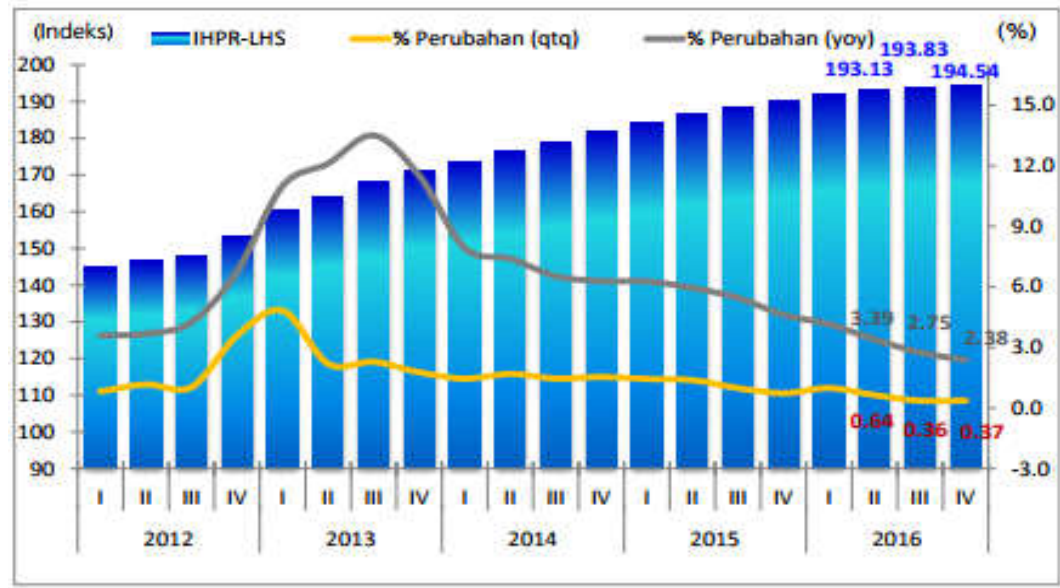

Figure 2 - Development of Residential Property Price Index (RPPI)

Meanwhile, the movement of property stock price, real estate, and building construction were fluctuative during the periode of 2012 to 2016. Table 1 depicts the development of stock return in the sector of property, real estate, and bulding construction from 2012 to 2016. The average of the lowest stock return was in 2015 , which was $-11.1 \%$. It generally indicates that the stock price of company sample was down. It is not in line with the raising price of commercial property in 2015.

Table 1 - The Movement of Stock Return Ratio for companies in the sectors of Real Estate and Building Construction during 2012-2016

\begin{tabular}{|c|c|c|c|}
\hline Year & Minimum & Maksimum & Mean \\
\hline 2012 & $-59.68 \%$ & $209.09 \%$ & $42.2 \%$ \\
\hline 2013 & $-74.86 \%$ & $1157.58 \%$ & $34.3 \%$ \\
\hline 2014 & $-42.05 \%$ & $208.19 \%$ & $37.3 \%$ \\
\hline 2015 & $-66.96 \%$ & $78.17 \%$ & $-11.1 \%$ \\
\hline 2016 & $-87.53 \%$ & $80.83 \%$ & $-0.52 \%$ \\
\hline
\end{tabular}

Table 2 - Average Return on Shares, CR, TATO, DER, ROE, TA and PBV of Property, Real Estate and Building Construction Sector Shares in the period 2012-2016

\begin{tabular}{|c|c|c|c|c|c|c|c|}
\hline Ket. & Return & CR & TATO & DER & ROE & TA & PBV \\
\hline 2012 & 0.42 & 2.65 & 0.32 & 1.02 & 0.12 & Rp4.38 & 1.77 \\
\hline 2013 & 0.34 & 3.54 & 0.32 & 1.09 & 0.14 & Rp5.83 & 1.85 \\
\hline 2014 & 0.37 & 2.78 & 0.31 & 1.06 & 0.12 & Rp6.91 & 2.19 \\
\hline 2015 & -0.11 & 3.19 & 0.28 & 0.87 & 0.09 & Rp8.11 & 1.70 \\
\hline 2016 & -0.005 & 3.19 & 0.28 & 0.87 & 0.09 & Rp9.22 & 1.29 \\
\hline
\end{tabular}


Table 2 illustrates that there is difference of movement of financial ration to stock return. The movement of the ratios is in line with the movement of stock return where the decline of return tends to be in line with the increase of PBV, TATO, DER, and ROE. However, the movement of stock return tends to be opposite with the ratio of CR and TA during the periode of 2012 to 2016. Based on the explanation above, the researcher takes the title of "Analysis The Effect of Fundamental Factor on Stock Return of Property (Case Study: Property, Real Estate and Building Construction Sector Companies listed on the Indonesia Stock Exchange from 2012 to 2016)".

\section{THEORITICAL REVIEW}

Signalling Theory. Sign or signal (Brigham, 2010) is an action that is conducted by management of the company in order to give hints to the investors about how they observe the prospect of the company. The company, which has great prospect of profitability, will try to avoid salling stock and find another way to get new financial funding. It includes the using of debt, which is up to the target of normal capital structure. The announcement of stocks emission is a sign that the prospect of the company is considered not good. If a company offers a new salling stock more often than the usual, then the price of its share will decrease because issuing a new share means giving a negative sign that can press the price of stocks even it has a great prospect.

Efficient Markets Hypothesis. Efficient Market Hypothesis (EMH) states that well organized capital markets are efficient markets. On the other word, inefficiency can probably happen, but it is relatively small and unusuall. In an efficient market, investor will get what they have been invested and the company will receive the stocks and obligations. Effeciency market is created by the competition of investors. They will continuily learn the historical financial of the company, how sensitive it is to the economic change, the amount of debt, and what kind of investment that has been done by a company until the information about the company`s share will be collected (Ross et al., 2000). According to Brigham (2010), the theory of the Efficient Markets Hypothesis confirms that (1) stocks are always in equilibrium and (2) it is impossible for the investors to "beat the market" and consistently gets a higer rate of return then what has been justified by the stock risk because the large number of full time professional analysts and the continuily observation of the stock movement in each industry.

Ratio Analysis. Financial ratio is designed to resume important information that is probably unclear if only checking financial report of a company (Brigham, 2010). Financial ratio is a relation that is determined from the financial information of a company and used to particulary comparison. Ross et al., (2000) says that by conducted an evaluation toward financial report from external party like short-term and long-term creditor as well as the candidate of investors will find information for determination of lending, financial stability of the company, knowing the competitor of the company, and capability of the company to grow and identify potential targets before investing. A trend of ratio will give a hint wheter the financial condition of a company tends to be great or not. To perform trend analysis, the ratio will be checked from time to time.

Issuer in Property, Real Estate and Building Construction. The issuers in Indonesia Stock Exchange can be classified into several sectors. The sectoral classification system that is used to categorize companies is listed in Indonesia Stock Exchange. It is known as Jakarta Stock Industrial Classification (JASICA). This catogorization can be used to analyze and evaluate listed companies in Indonesia Stock Exchange. So, it is expected to help making decision in investing. Indonesia Stock Exchange also calculates sectoral index as performance indocator for each industry. JASICA is launched in Desember $28^{\text {th, }} 1995$ with 9 main classifications. They are: (1) agriculture sectors, (2) mining sectors, (3) basic industry and chemical sectors, (4) various industry sectors, (5) consumer goods industry sectors, (6) property, real estate and building construction sectors, (7) infrastructure, utilities and transportation sectors, (8) financial sectors, and (9) trade, service and investment sectors. 
Business Challenges for Property, Real Estate, and Building Construction. The property sector has recorded a deceleration over the past 3 years. Some of the things that led to the retardation include the macro prudential policy of Bank Indonesia, concerned about the rise in tax rates for property, and the weakening of people's purchasing power. Indonesia has a large population, which is over 255 million people in which, $60 \%$ of them are in productive age. This creates a huge demand for the property, real estate and building construction sectors. The necessity of new houses that is caused by the growth of population and the urbanization per year reaches 800 thousand units. The prospect of growth in the sector of property, real estate, and building construction is massive. The successful of Amnesty Program can help the sector of property to growth because previously, there is no tax certainty tax, which can make consumer, hesitates to buy a new property. In 2016, Bank Indonesia also lowered the benchmark interest rate to $4.75 \%$, which can give great prospect for the future. Currently, interest rates of House Ownership Credit (HOC) is relatively low if it is compared to the previous years, which is related to the decline in interest rates of Bank Indonesia. The decrease of final Income Tax from 5\% to $2.5 \%$ in 2016 also increase the profit for developers.

The acceleration of infrastructure projects can become a prospect of development of property in the upcoming years. Several important projects such as Jakarta Bandung High Speed Rail (HRS), Jakarta Mass Rapid Transit (MRT), Light Rapid Transit (LRT), and highway such as trans Java \& Sumatera, JORR W2, and others. A fast and great infrastructure construction will create transportation pathway, in which will encourage more people to buy property outside of Jakarta because it is cheaper than leasing in the urban Jakarta. Therefore, it will give positive effect for properties and real estate demand. On the other hand, this sector has growth challenging like the increasing of acquisition price and the difficulty of acquiring new land with an average increase of $10 \%-20 \%$ per year, the decrease of purchasing power, so that it is difficult for the developers to increase the selling price. Business of hospitality in Indonesia is currently going down because of the new regulation that civil servants are not allowed to do activity in the hotel. It can automatically decrease the income in hospitality sector. In 2015, the government has issued the regulation about allowing foreigners to live and buy a land or apartment in Indonesia under the regulation of the Ministry of Agrarian Affairs.

However, this regulation is still considered detrimental for buyers because expatriates cannot obtain the Certificate of Ownership and only have the Right to Use applicable for 30 years with option of extension twice. They can only buy property directly from developers then they are not allowed to rent their property to the third party, and there is minimum price of special property for them. Since 2013, the government has also imposed restriction for loan of property, which is still under construction. Developer will only receive the payment from the bank according to the percentage of accomplishment of the project. Nonetheless, this policy is loosened in 2016, in which the regulation is not imposed for second house buyer.

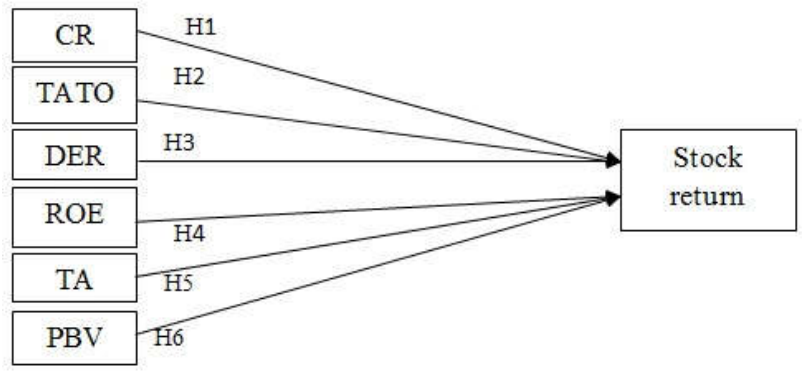

Figure 3 - Theoretical Framework

Research hypothesis. Based on the framework, then the hypothesis proposed in this research are as follow: 
H1: Current Ratio (CR) has a positive or negative and significant impact on stock returns on the property sector, real estate and building construction.

H2: Total Asset Turnover (TATO) has a positive or negative and significant impact on stock returns on the property sector, real estate and building construction.

H3: Debt to Equity Ratio (DER) has a positive or negative and significant impact on stock returns on the property sector, real estate and building construction

H4: Return on Equity (ROE) has a positive or negative and significant impact on stock returns on the property sector, real estate and building construction.

H5: Total Assets (TA) has a positive or negative and significant impact on stock returns on the property sector, real estate and building construction.

H6: Price to Book Value (PBV) has a positive or negative and significant impact on stock returns on the property sector, real estate and building construction.

\section{METHODS OF RESEARCH}

This research takes the population of all company in property sector, real estate, and building construction that listed in Indonesia Stock Exchange in the period from 2012 until 2016 with the total of 62 companies as the research population. Sample collection technique used in this research is purposive sampling, which members of the sample will be selected in such a way that the established sample may represent the properties of the population (Sugiyono, 2013). The sample criteria in this research are (1) Issuer listed in Indonesia Stock Exchange which can be accessed on www.idx.co.id as the issuer which submit the financial statements and has the completeness of data during the research period. The data of financial statements required in this research are Total Assets, Net Income, Total Equity, Total Debt, Total Revenue / Sales, Fixed Assets, Current Assets, Current Debts, and Book Value, (2) The issuer has done Initial Public Offering before 2012 so the data of stock price reflects the stock price in the market for 5 years to avoid any mistakes in data processing.

Based on the sample collection criteria above, then there are 41 companies in Property Sector, Real Estate, and Building Construction in 2016 as the sample of this research. Type of data used in this research is secondary data which is quantitative and in a form of data panel which combined the data of time series and cross section. Data panel depicts two types of information that are: information of cross section on the difference between subject, and information of time-series which reflects the changes at a certain time. The data obtained from the companies' financial statements which have been audited and published. The researcher obtained the data through Indonesia Stock Exchange website (www.idx.co.id).

Data collection technique in this research is by documenting which is collecting all the published data from the Indonesia Stock Exchange website. Number documentation on sample companies' financial statements with the defined criteria and literature review, which is various literature that related with the problems in the research obtained from the books or journals which have been published before.

This research tested the influence of more than one independent variable to one dependent variable, then the research using multiple regression. The steps in estimating the regression model with panel data is done by creating a Common Effect regression, and then creating a Fixed Effect regression, and finally creating a random effect regression. The selection between the Common Effect and Fixed Effect model is done by Chow test or F-test. The selection between Fixed Effect and random effect model is done by Hausman test. The selection between the Common Effect and the random effect model is done by the LM test. To determine the exact model, then this research performed some tests such as F statistical test (Chow test), Hausman test, and Lagrange Multiplier Test. Hypothesis testing in this research was tested based on selected panel data model. Furthermore, the interpretation of data is by looking at Coefficient of Determination $\left(R^{2}\right)$, Simultaneous Significance Test ( $F$ Statistic Test) and Partial Individual Significance Test (T Statistic Test). 


\section{RESULTS AND DISCUSSION}

Chow Test. Chow test is done to determine whether the right model of the equation is pooled least square (Common Effect) or Fixed Effect. This is determined from the result of Chi-square probability. The following is the result of Chow Test in this research:

Table 4 - Chow Test Result

Redundant Fixed Effects Tests

Pool: Untitled

Test cross-section fixed effects

\begin{tabular}{lrrr}
\hline \hline Effects Test & Statistic & d.f. & Prob. \\
\hline \hline Cross-section F & 0.955263 & $(40,157)$ & 0.5524 \\
Cross-section Chi-square & 44.655713 & 40 & 0.2825 \\
\hline \hline
\end{tabular}

If the result of Chi-Square probability is $<0.05$, then the right model to be used is Fixed Effect. From table 4 above, the value of Chi-Square probability is 0.2595 or greater than $>0.05$, then the right model is Common Effect.

Hausman Test. The next testing is to test between Fixed Effect and Random Effect by doing Hausman Test. If Hausman Test results the value of Chi-Square probability is $<0.05$, then the right model is Fixed Effect, and if the value of Chi-Square probability is $>0.05$, then the right model is Random Effect. The following is the result of Hausman Test in this research:

Table 5 - Hausman Test Result

\begin{tabular}{|c|c|c|c|}
\hline Test Summary & Chi-Sq. Statistic & Chi-Sq. d.f. & Prob. \\
\hline Cross-section random & 9.440119 & 6 & 0.1503 \\
\hline
\end{tabular}

From table 5 above, the value of chi-square probability is 0.1503 or greater than $>0.05$, so the right model is Random Effect.

Lagrange Multiplier Test. This test is used to find a better model between pooled least square (Common Effect) and random effect. If the Breusch- Pagan count value is $<0.05$, then the best model is random effect, and if the Breusch- Pagan count value is $>0.05$, then the best model is Common Effect. The following is the result of Lagrange Multiplier test in this research:

Table 6 - Lagrange Multiplier Test Result

Lagrange Multiplier Tests for Random Effects

Null hypotheses: No effects

Alternative hypotheses: Two-sided (Breusch-Pagan) and one-sided

(all others) alternatives

\begin{tabular}{lccc}
\hline \hline & \multicolumn{3}{c}{ Test Hypothesis } \\
& Cross-section & Time & Both \\
\hline \hline \multirow{2}{*}{ Breusch-Pagan } & $\begin{array}{l}0.685377 \\
(0.4077)\end{array}$ & $\begin{array}{l}0.984689 \\
(0.3210)\end{array}$ & $\begin{array}{l}1.670067 \\
(0.1962)\end{array}$
\end{tabular}


From table 6 above, the Breusch- Pagan count value (BP) is 0.4077 . The value is greater than 0.05 , so the best model in this research is Common Effect. From the three panel model above, the use of Common Effect mode; will be analyzed further in this research.

Model Estimation Result (Common Effect Model). Estimation of panel data regression with Common Effect model is showed on table 7 as follow:

Table 7 - Common Effects Model Test Result

\begin{tabular}{|c|c|c|c|c|}
\hline \multicolumn{5}{|c|}{$\begin{array}{l}\text { Dependent Variable: RETURNSAHAM? } \\
\text { Method: Pooled Least Squares } \\
\text { Date: } 04 / 13 / 18 \text { Time: } 10: 46 \\
\text { Sample: } 20122016 \\
\text { Included observations: } 5 \\
\text { Cross-sections included: } 41 \\
\text { Total pool (balanced) observations: } 205 \\
\end{array}$} \\
\hline Variable & Coefficient & Std. Error & $\mathrm{t}$-Statistic & Prob. \\
\hline C & -0.460674 & 1.254406 & -0.367244 & 0.7138 \\
\hline CR? & 0.011655 & 0.013189 & 0.883678 & 0.3779 \\
\hline TATO? & -0.805384 & 0.331385 & -2.430357 & 0.0160 \\
\hline DER? & 0.185795 & 0.078425 & 2.369086 & 0.0188 \\
\hline ROE? & 0.833938 & 0.598002 & 1.394542 & 0.1647 \\
\hline TA? & 0.011827 & 0.043458 & 0.272156 & 0.7858 \\
\hline PBV? & 0.145083 & 0.046556 & 3.116294 & 0.0021 \\
\hline R-squared & 0.098574 & \multicolumn{2}{|c|}{ Mean dependent var } & 0.204493 \\
\hline Adjusted R-squared & 0.071258 & \multicolumn{2}{|c|}{ S.D. dependent var } & 0.957312 \\
\hline S.E. of regression & 0.922574 & \multicolumn{2}{|c|}{ Akaike info criterion } & 2.710251 \\
\hline Sum squared resid & 168.5261 & \multicolumn{2}{|c|}{ Schwarz criterion } & 2.823719 \\
\hline Log likelihood & -270.8007 & \multicolumn{2}{|c|}{ Hannan-Quinn criter. } & 2.756146 \\
\hline F-statistic & 3.608653 & \multirow{2}{*}{\multicolumn{2}{|c|}{ Durbin-Watson stat }} & 2.512493 \\
\hline Prob(F-statistic) & 0.002032 & & & \\
\hline
\end{tabular}
follow:

Based on the analysis result of multiple regression, then the regression equation is as $Y=-0.460674+0.011655 C R-0.805384$ TATO $+0.185795 D E R+0.833938 R O E+0.011827 T A+0.145083 P B V$

Constant $a$ is -0.460674 , it states that if the variables $X 1, X 2, X 3, X 4, X 5, X 6$ and $X 7$ is constant, then the $Y$ variable is -0.460674 . Regression coefficient of $X 1-X 7$ states that every increase of each independent variable by $1 \%$ will impact on the increase of stock returns in property sector, real estate, and building construction in the amount of the regression coefficient with the assumption that other independent variables are constant. The value of Adjusted $R^{2}$ is 0,071258 which implies that the influence of independent variables like Price to Book Value (PBV), Current Ratio (CR), Return on Equity (ROE), Debt to Equity Ratio (DER), Total Asset Turn Over (TATO), and Total Assets (TA) to stock returns on property sector, real estate, and building construction of $7.12 \%$, while the rest can be influenced by other variables that cannot be explained in this research model. The small value of Adjusted $\mathrm{R}^{2}$ can be accepted in the panel data which already combined the cross section and time series data.

The next one is testing the level of significance on each coefficient in the partial regression equation. To find the $t$ table, the researcher used the real level $(\alpha)=0.05$, and obtained the $t$ table equal to 1.97202 . The count value of $t$ for the Current Ratio $(C R)$ variable is greater than the value of $t$ table that is $0.883678 \leq 1.97202$ or significance $t(0.025)>\alpha$ (0.05). So it can be concluded that the Current Ratio (CR) variable partially has a positive but not significant effect on stock return of property, real estate and building construction on the 2012-2016 period. 2) The $t$ value for the Total Asset Turn Over (TATO) variable is greater than the value of $-t$ table that is $-1.97202 \leq-2.430357$ or significance $t(0.025)<\alpha(0.05)$. So, it can be concluded that the Total Asset Turn Over (TATO) variable partially has a negative 
and significant effect on stock returns of property, real estate and building construction on the 2012-2016 period.

The count value of $t$ for the Debt to Equity Ratio (DER) variable is greater than the value of $t$ table that is $2.369086>1.97202$ or significance $t(0.025)<\alpha(0.05)$. So it can be concluded that the Debt to Equity Ratio (DER) variable partially has a positive and significant effect on stock return of property, real estate and building construction on the 2012-2016 period. The count value of $t$ for the Return on Equity (ROE) variable is greater than the value of $t$ table that is $1.97202>1.394542$ or significance $t(0.025)<\alpha(0.05)$. So it can be concluded that the Return on Equity (ROE) variable partially has a positive but not significant effect on stock return of property, real estate and building construction on the 2012-2016 period. The count value of $t$ for the Total Assets (TA) variable is greater than the value of $-t$ table that is $0.272156 \leq 1.97202$ or significance $t(0.025)>\alpha(0.05)$. So it can be concluded that the Total Assets (TA) variable partially has a positive but not significant effect on stock returns of property, real estate and building construction on the 2012-2016 period. The count value of $t$ for the Price to Book Value (PBV) variable is greater than the value table that is $3.116294>1.97202$ or significance $t(0.027)<\alpha(0.05)$. So it can be concluded that the Price to Book Value (PBV) variable partially has a positive and significant effect on stock return of property, real estate and building construction on the 2012-2016 period.

The research tested the significant testing simultaneously (overall significance) on a regression equation based on hypothesis test. The analysis result which was estimated on table 7 shows that the count value if $F=3.608653$ while the value of $F$ table on $\alpha=0.05$ and the free degree (dk) quantifier $=7, n=205$, the free degree (dk) quantifier $=197$ is 2.06 . So $F$ $=3.608653>\mathrm{F}$ table $=2.06$ implies that $\mathrm{HO}$ is rejected and $\mathrm{Ha}$ is accepted on the level of significance $\alpha=0.05$. Therefore, it can be concluded that variables of Price to Book Value (PBV), Current Ratio (CR), Return on Equity (ROE), Debt to Equity Ratio (DER), Total Asset Turn Over (TATO), and Total Assets (TA) together have significant effect on stock return of property company, real estate and building construction on the 2012-2016 period.

\section{DISCUSSION OF RESULTS}

Current Ratio (CR) has a positive but not significant effect on stock returns of property, real estate and building construction. CR shows the liquidity of the company between the compositions of the company's current assets with its current liabilities. This research is in accordance with the research of Ariyanti (2016). Total Asset Turn Over (TATO) has a negative and significant influence on stock returns of property, real estate and building construction. TATO indicates the company's efficiency in using its assets to generate revenue. In theory, TATO reflects the company's ability in managing assets efficiently to earn revenue from operational activities, so the higher TATO is expected to bring a positive impact on stock returns. However, research shows that the negative influence between TATO and stock return can be caused by the dominance of large companies in obtaining high stock returns, where large companies usually have difficulties to increase the ratio of TATO easily.

Another factor is the stock return which can also be affected by non-operational profits that are not obtained from the main sales. This research is in accordance with the research of Martani (2009) and Stefano (2015). Debt to Equity Ratio (DER) has a positive and significant effect on stock returns of property, real estate and building construction. DER shows the level of company solvency which measures the total composition of the company's debt compared to its total equity. The result of the research shows that the increase of DER reflects the company's ability in exploiting the debt to get bigger profit per share which also increases the stock return of the company.

This research is in accordance with the research of Nidianti (2013) and Sutriani (2014). Investors can see DER as a guarantee of the size of the company's liability to the lender who provides the loan. The high DER reflects the huge debt value that investors perceive as additional funds that can be used for the company's operations. When the source of debt funds can be managed properly then the company obtain optimal profit. Information of DER changes may affect investors' decisions to invest in companies. Return on Equity (ROE) has 
a positive but not significant effect on stock returns of property, real estate and building construction. The result shows that the increase in ROE does not have a significant impact on the increase of stock returns. This study is in accordance with the research of Kohansal (2013), Anwaar (2016), and Kusuma (2016).

Total Assets (TA) has a positive but not significant effect on stock returns of property, real estate and building construction. This study is in line with the research of Absari (2013) which states that Total Assets (TA) has no effect on stock returns. Price to Book Value (PBV) has a positive and significant effect on stock returns of property, real estate and building construction. The PBV shows a comparison between the stock price and the book value of the shares. The result shows that PBV ratio has a positive effect on stock return. The PBV demonstrates the success of management in managing corporate resources that reflects the company's share price at the end of the year. The higher the PBV will give investors an expectation of greater profit. This study is in accordance with the research of Wijesundera (2015), Khotimah (2015), Meesuwan (2015), Djamaluddin (2015), and Moshavegh and Amirhossie (2016).

\section{CONCLUSION AND RECOMMENDATIONS}

Based on the result of the research, it can be concluded that the ratio of Total Asset Turn Over (TATO) partially has negative and significant effect on the stock return of property company, real estate and bulding construction which listed on Indonesia Stock Exchange on 2012-2016 period, while Debt to Equity Ratio (DER) and Price to Book Value (PBV) partially has positive and significant effect on the stock return of property company, real estate, and building construction which listed on Indonesia Stock Exchange on 2012-2016 period. Meanwhile the ratio of Current Ratio (CR), Return on Equity (ROE), and Total Assets (TA) partially have no significant effect on the stock return of property company, real estate, and building construction which listed on Indonesia Stock Exchange on 2012-2016 period.

For the researchers who are interested to research and develop this study, some of the recommendations are such as to research other sectors, add the number of the sample issuers, and research other factors, which can influence the stock return of the company but have not been researched in this study. The next study can use other variables like inflation, exchange rate, or other sector of economy macro as independent variable.

\section{REFERENCES}

1. Absari, D. U. A., Sudarma, M., \& Chandrarin, G. (2013). Analisis Pengaruh Faktor Fundamental Perusahaan Dan Risiko Sistematis Terhadap Return Saham. El Muhasaba: Jurnal Akuntansi, 3(2).

2. Anwaar, M. (2016). Impact of Firms Performance on Stock Returns (Evidence from Listed Companies of FTSE-100 Index London, UK). Global Journal of Management And Business Research.

3. Ariyanti, A. I., \& Suwitho, S. (2016). Pengaruh Cr, Tato, Npm Dan Roa Terhadap Return Saham. Jurnal IImu \& Riset Manajemen, 5(4).

4. Brigham. (2010). Financial Management Theory and Practice. Edisi Ketigabelas: South Western Cengange Learning. California.

5. Djamaluddin, S., Rahmawati, D., \& Hapzi, A. (2015). "The Influence of Fundamental Factors Micro and Macro to Return Expected through The Intervening Corporate Value in The Listed Real Estate Sector in BEI Periode 2011-2014". International Journal of Business and Management Invention. Vol 6, No.2, pp 14-22.

6. Halim, A. (200)5. Analisis Investasi. Jakarta: Salemba Empat.

7. Khotimah, K., \& Murtaqi, I. (2015). "The Fundamental Analysis of Indonesian Stock Return (Case Study: Listed Public Companies in Sub-Sector Food and Beverage for The Period 2003-2012)". Journal of Business and Management. Vol. 4, No.1, pp. 95-104. 
8. Kohansal, M. R., Dadrasmoghadam, A., Mahjori Karmozdi, K., \& Mohseni, A. (2013). Relationship between financial ratios and stock prices for the food industry firms in stock exchange of Iran. World Applied Programming, 3.

9. Kusuma, I.L. (2016). Pengaruh Asset Growth, Debt To Equity Ratio, Return On Equity, Total Asset Turnover Dan Earning Per Share terhadap Beta Saham Pada Perusahaan yang Masuk dalam Kelompok Jakarta Islamic Index (JII) Periode 2013-2015. Jurnal Riset Akuntansi dan Keuangan. Vol.4, No.2, p. 1005-1020.

10. Martani, D., \& Khairurizka, R. (2009). The effect of financial ratios, firm size, and cash flow from operating activities in the interim report to the stock return. Chinese Business Review, 8(6), 44.

11. Meesuwan, N. (2015). Stock Return Predictability with Financial Ratios: A Panel Data Analysis in The Stock Exchange of Thailand (SET). Senior Research. Bachelor Arts Degree in Economics. Chulalongkorn University. Thailand.

12. Moshavegh, S., \& Montazerhojat, A. (2016). Examining the Relationship between Financial Ratios and Stock Returns of Companies Listed on Tehran Stock Exchange (Chemical, Biotechnology Products and Non-metallic Minerals Industry). Bulletin of Environment, Pharmacology and Life Sciences. Vol. 1. pp 31-34.

13. Nidianti, P.I. (2013). Pengaruh Faktor Internal dan Eksternal Perusahaan Terhadap Return Saham Food and Beverages di Bursa Efek Indonesia. e-Journal Akuntansi Universitas Udayana Vol 5. No.1, pp 130-146.

14. Ross, S. A., Westerfield, R., Jordan, B. D., \& Firer, C. (2000). Fundamentals of corporate finance. Boston, MA: Irwin/McGraw-Hill.

15. Stefano, K. (2015). The Impact of Financial Ratio toward Stock Return of Property Industry in Indonesia. iBuss Management, 3(2).

16. Sugiyono. (2013). Metode Penelitian Manajemen. Bandung : Alfabeta.

17. Sutriani, A. (2014). Pengaruh profitabilitas, leverage, dan likuiditas terhadap return saham dengan nilai tukar sebagai variabel moderasi pada saham LQ-45. Journal of Business \& Banking, 4(1), 67-80.

18. Wijesundera, A. A. V. I., Weerasinghe, D. A. S., Krishna, T. P. C. R., Gunawardena, M. M. D., \& Peiris, H. R. I. (2015). Predictability of stock returns using financial ratios: empirical evidence from Colombo stock exchange. Kelaniya Journal of Management. Vol. 4, No. 2, pp 44-55. 